FOR REFERENCE

NOT TO BE TAKEN

FFOM THIS ROOM

w. T. Cons

MLM-MU-77-72-0002

\title{
Proposal to Process RTNS-II \\ Accelerator Targets for LLL
}

\author{
E. A. Mershad, W. A. Clift, R. E. Wieneke, \\ D. L. Coffey, G. V. Nesslage, L. W: Metcalf
}

and R. A. Watkins

December 20, 1977

$$
\text { RECEVEO }
$$

JUL 011 ISPS
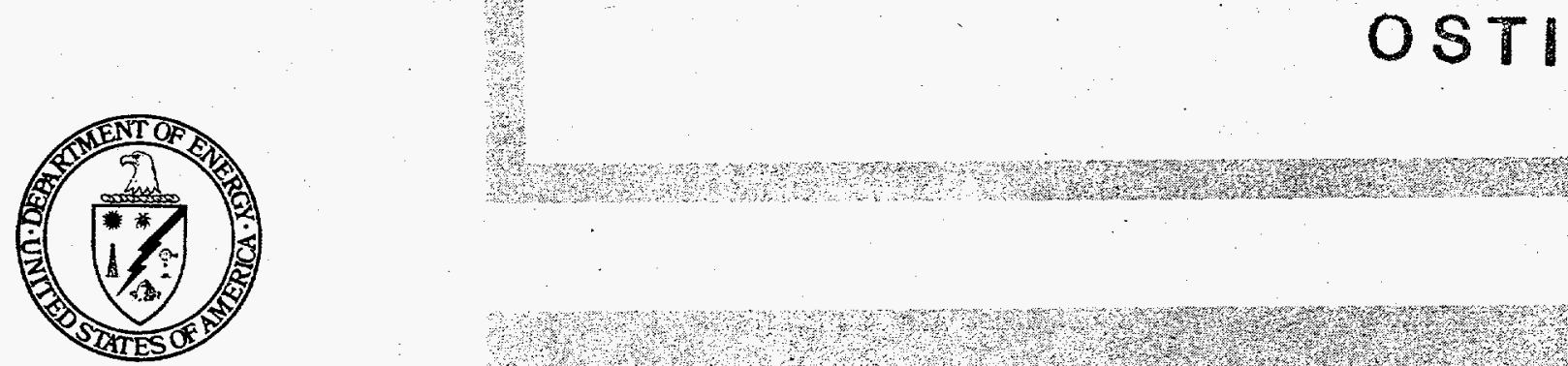

\section{MOUND FACILITY}

Miamisburg, Dhio

operated by

MONSANTO RESEARCH CORPORATION a subsidiany of Monsanto Eompany

for the

U. S. DEPARTMENT OF ENERGY

Contract No. EY-7B-O 4003

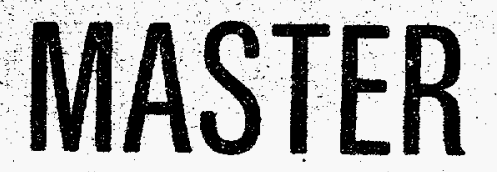

DISTABUTTON OF THS OOCUMENT IS UNIMTED DLE 


\title{
Proposal to Process RTNS-II Accelerator Targets for LLL
}

\author{
E. A. Mershad, W. A. Clift, R. E. Wieneke, \\ D. L. Coffey, G. V. Nesslage, L. W. Metcalf \\ and R. A. Watkins
}

Issued: December 20, 1977

DISCLAIMER

This report was prepared as an account of work sponsored by an agency of the United States Government. Neither the United States Government nor any agency thereof, nor any of their employees, makes any warranty, express or implied, or assumes any legal liability or responsibility for the accuracy, completeness, or usefulness of any information, apparatus, product, or process disclosed, or represents that its use would not infringe privately owned rights. Reference herein to any specific commercial product, process, or service by trade name, trademark, manufacturer, or otherwise does not necessarily constitute or imply its endorsement, recommendation, or favoring by the United States Government or any agency thereof. The views and opinions of authors expressed herein do not necessarily state or reflect those of the United States Government or any agency thereof.

\author{
MOUND FACILITY \\ Miarnisburg, Ohio 45342 \\ operated by \\ MONSANTO RESEARCH CORPORATION \\ a subsidiary of Monsanto Company \\ for the \\ U. S. DEPARTMENT OF ENERGY \\ Contract No. EY-76-C-04-0053
}


TABLE OF CONTENTS

Page

1. INTRODUCTION

1.1. INTRODUCTION . . . . . . . . . . . . .

2. FACILITIES

2.1. FACILITIES DESCRIPTION . . . . . . . . . . 4

2.2. FACILITY COSTS . . . . . . . . . . . . . 10

2.3. OPTIONAL FACILITY . . . . . . . . . . . . 13

2.4. PACKAGING COSTS . . . . . . . . . . . . 13

3. PROCESS OPERATIONS

3.1. INTRODUCTION . . . . . . . . . . . . . 16

3.2. NEW TARGET PROCESSING . . . . . . . . . . . 16

3.3. EXPENDED TARGET PROCESSING •. •......... . . 17

3.4. TRITIUM RECOVERY AND ENRICHMENT . . . . . . . . 18

3.5. OPERATING COSTS . . . . . . . . . . . 20

4. HAZARDS EVALUATION

4.1. SUMMARY . . . . . . . . . . . . . . . . 21

4.2. INTRODUCTION . . . . . . . . . . . . . . . . . 21

4.3. PROCESS SAFETY AND ENVIRONMENTAL PROTECTION FEATURES 21

4.4. ACCIDENT ANALYSIS . . . . . . . . . . . . . 24

5. DISTRIBUTION . . . . . . . . . . . . . . . . . 30 


\section{INTRODUCTION}

\subsection{INTRODUCTION}

This proposal is submitted in response to a programmatic need at LLL for a supplier of $50-\mathrm{cm}$ targets (tritided) for the new RTNS-II facility. Previous letters of inquiry to Mound also delineate a need for recovery of tritium from expended RTNS-II targets. As explained in this proposal, the tritided target manufacturing and tritium recovery can be accomplished in an efficient and timely manner at Mound Facility.

Mound has been a major tritium handling facility for over $20 \mathrm{yr}$ : Multigram quantities of tritium are routinely handled in various production, recovery, research, and development processes. Mound presently recovers tritium gases from various solid waste forms and enriches these gases to greater than $99 \%$ tritium. Other work assignments involve operations that utilize thin film vacuum evaporators for occluder deposition of different metals. Metal hydride know-how is also an integral part of various ongoing programs. Mound is widely recognized as a leader in the design, installation, and operation of high-purity glovebox atmosphere systems, and tritium containment, effluent control, and waste packaging systems. Demonstrated performance and experience in these strategic technology areas makes this facility ideally suited for meeting LLL's tritided accelerator target needs.

Components produced at Mound are subjected to a very comprehensive quality control (QC) program. Specific QC programs are developed for each product. It is a negotiated QC program that is mutually acceptable to Mound and the customer. The goal of the QC program is to preclude defectiveness by the effective control and management of variation, within specified limits, from raw material to finished product including handling, packaging, and shipment.

As a prelude to preparation of this proposal for presentation to LLL, Mound personnel visited William C. Brown and James L. Provo at GEND to review GEND experience in fabrication of RTNS-I (9.0-in. or 23-cm diameter) targets and obtain their guidance for fabrication of RTNS-II targets.

After consolidation and evaluation of various inputs of information, we feel confident that Mound can fabricate and recover RTNS-II targets to meet LLL requirements. This proposal, therefore, outlines our plan for performing this work and requests that Mound Facility be designated by LLL as the fabrication and recovery site for large-diameter fully tritided accelerator targets. 


\section{FACILITIES}

\subsection{FACILITIES DESCRIPTION}

Existing Building

The proposed production facility for processing neutron targets would be installed in the existing $\mathrm{R}$ Building at Mound Facility. The $\mathrm{R}$ Building is a one-story structure, of steel and concrete block with brick facing, originally built as a research laboratory for radioactive materials. The location of $\mathrm{R}$ Building is shown in the Mound Facility Site Plan (Figure 1, p. 5). A plan view of the $R$ Building is shown in Figure 2, p. 6 .

The air supply system for the building is equipped to provide the proper temperature and humidity control for a tritium processing facility. Emergency power for the building ventilation system is furnished by a $500-\mathrm{kW}$ diese1-driven generator. Minor revisions to the ventilation system are necessary to isolate this facility from adjacent areas handling other materials.

Two 1000-kVA substations provide power for the $\mathrm{R}$ Building. Sufficient power is available for the proposed facility but some additional switch gear, conduit and power panels wịl be installed.

Proper fire doors are installed throughout the $\mathrm{R}$ Building, and the entire building is sprinkler protected. No major modification to the existing fire protection system is anticipated.

A 60-ft $/$ min effluent removal system (ERS) (Figure 7, p. 23) is located in the SW Building which is adjacent to the R Building; a common corridor joins the two buildings. This system has been in use for over $12 \mathrm{yr}$ to support existing tritium processing facilities. The system is used to remove tritium, as water, from the effluents of various support equipment such as vacuum pumps and glovebox atmosphere purifiers before the effluent gases are exhausted to the atmosphere.

The ERS occupies approximately $2000 \mathrm{ft}^{2}$ of floor space; it has been upgraded in capability several times, and its estimated capital value is $\$ 1,250,000$. This facility can be utilized at no additional cost. With the addition of a double-walled pipeline connecting the proposed Neutron Target Facility to R-107 (both adjacent to common corridor 2), all necessary tritium recovery, enrichment, and effluent control systems are available to support the proposed facility. 


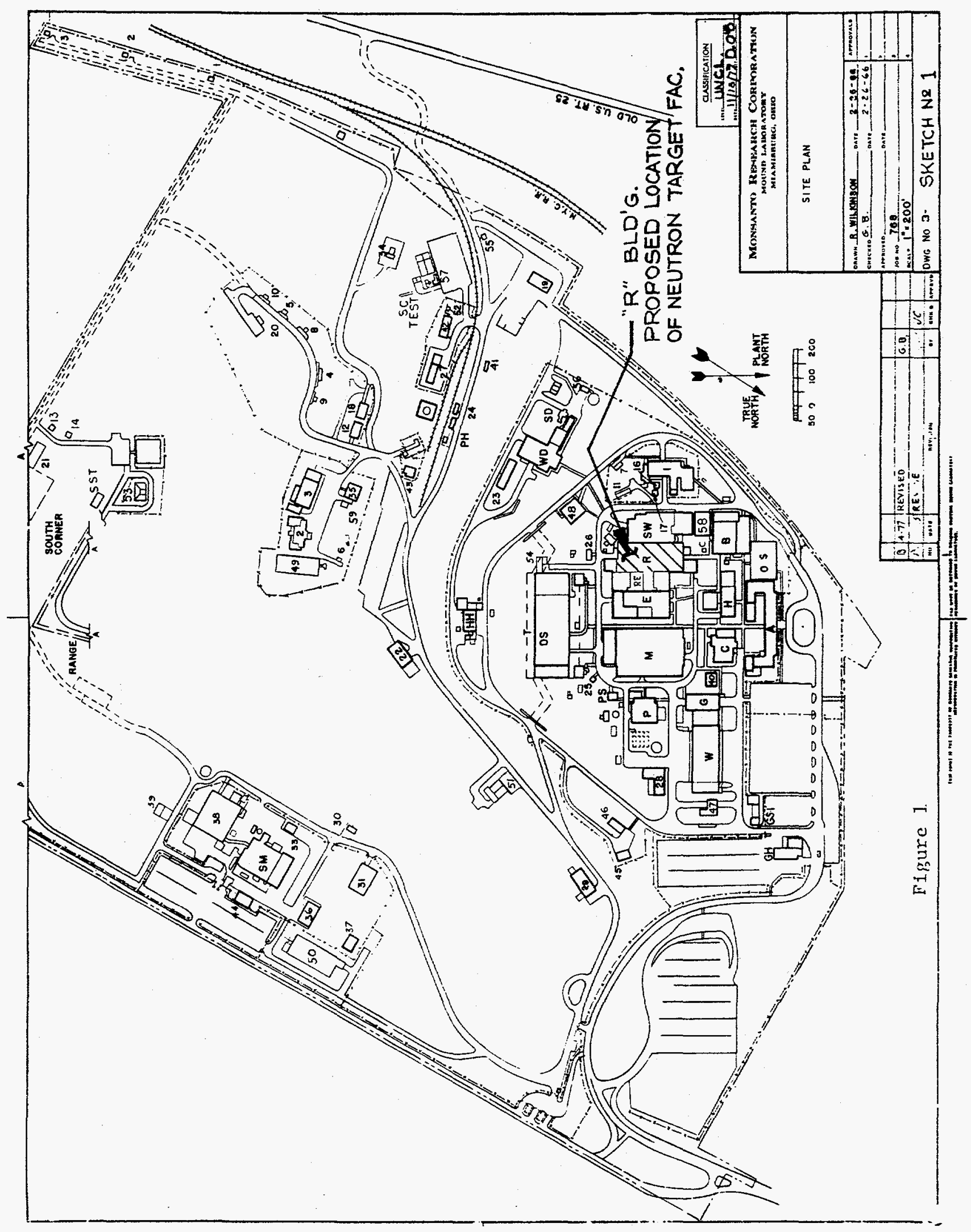



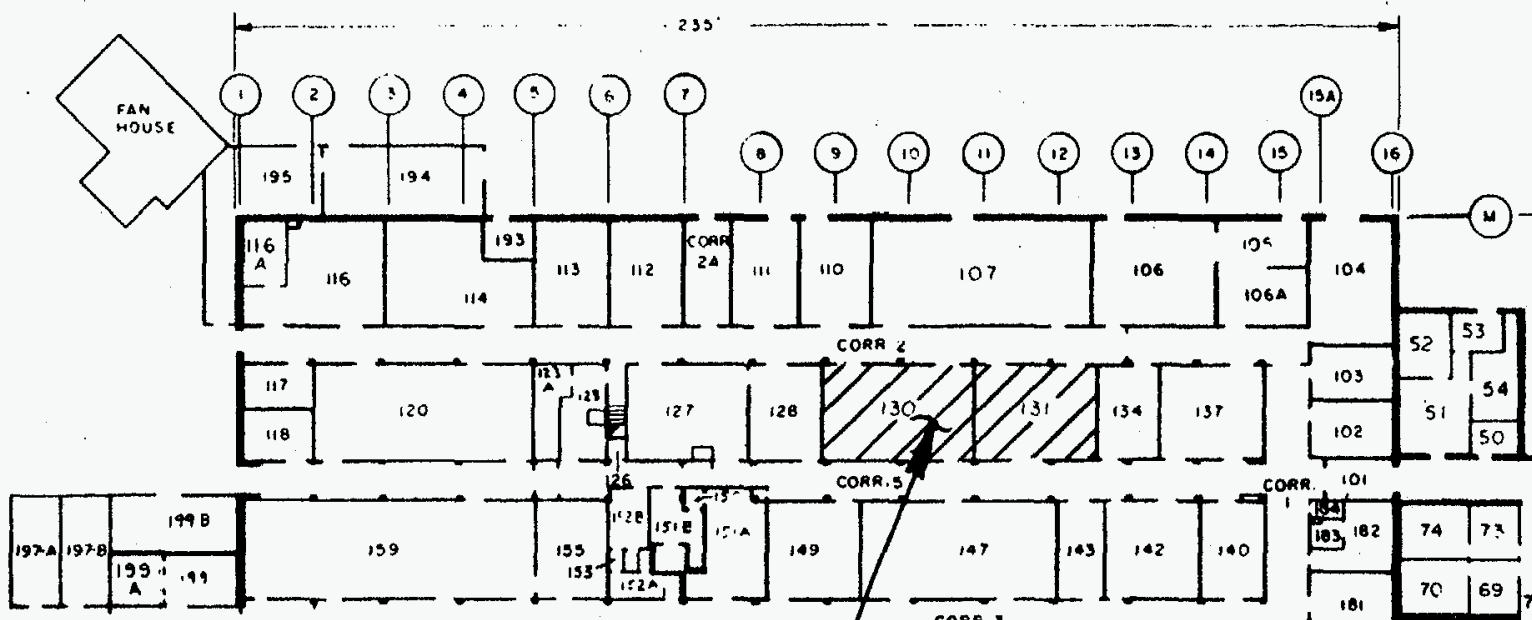

\begin{tabular}{|l|l}
\hline & \\
\hline 101 & \\
\hline
\end{tabular} ${ }^{21}$

L

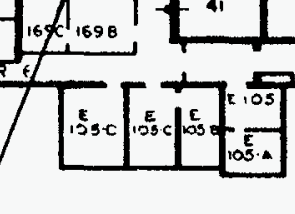

PROPOSED LOCATION OF NEUTRON TARGET FACILITY

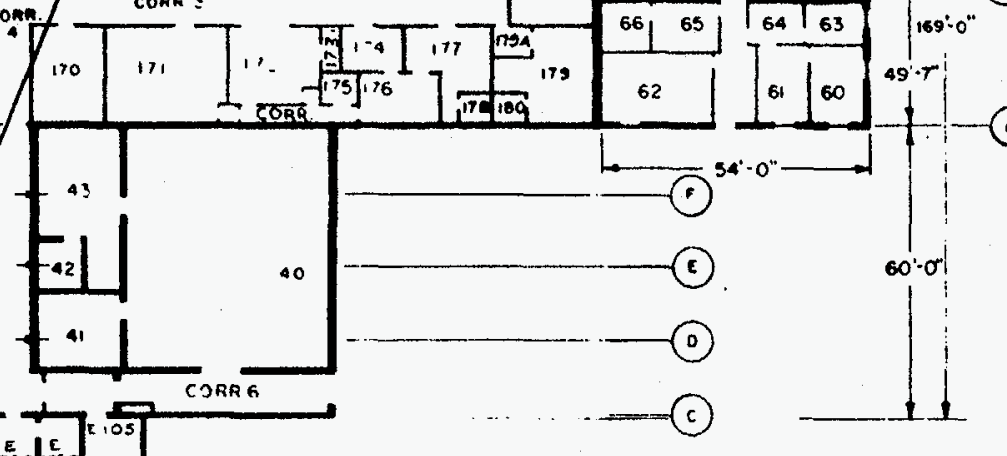


Also located in the SW Building is a facility for evaluation of the tritium content and packaging for disposal of liquid wastes such as vacuum pump oil and water which contain high levels of tritium. The equipment occupies $300 \mathrm{ft}^{2}$ of floor space, has a capital value of about $\$ 200,000$, and will be used to support the Neutron Target Facility at no additional cost. An addition to the SW Building for increasing this capability, entitled "Fixation of Aqueous Tritiated Waste," estimated at $\$ 610,000$ is presently scheduled as a FY-1979 GPP item. All packaged radioactive waste is transferred to a waste staging and storage building for offsite shipment and burial.

\section{New Process Equipment}

The proposed facility will be installed in rooms $\mathrm{R}-130$ and $\mathrm{R}-131$. These rooms are presently in use but current decommissioning and decontamination planning indicate that the rooms will become available for use as the proposed facility. A new glovebox line will be installed as shown in Figure 3, p. 8. New wall partitions will be erected to enclose the inert-gas purifier. These partitions isolate the purifier from the production area, facilitate maintenance, and minimize downtime due to contamination. Five new gloveboxes are planned for this facility: an entry/exit glovebox with fume hood, a load/unload glovebox, a cleaning glovebox, a hydride glovebox and a vapor deposition glovebox. All of the processing equipment will be installed inside these gloveboxes in which a high-purity argon atmosphere will be maintained. A flow diagram representing the various operations performed in this facility is shown in Figure 6, p. 19.

Two major systems are included in this facility: the vacuum deposition system and a combination vacuum/hydrogen furnace.

The vacuum deposition system consists of a vacuum pumping system, a vacuum chamber and electron beam guns for film deposition.

The pumping system will include a 10-in. diffusion pump with a pumping speed of 3500 liters/sec (capable of pumpdown to $1 \times 10^{-7}$ torr), an optically dense chevron-type baffle, an automatic filling liquid nitrogen trap, and a $36-\mathrm{ft}^{3} / \mathrm{min}$ direct-drive mechanical pump. Foreline and roughing valves will be $2-i n$. stainless steel air-operated gate valves, and the high-vacuum valve will be a. 


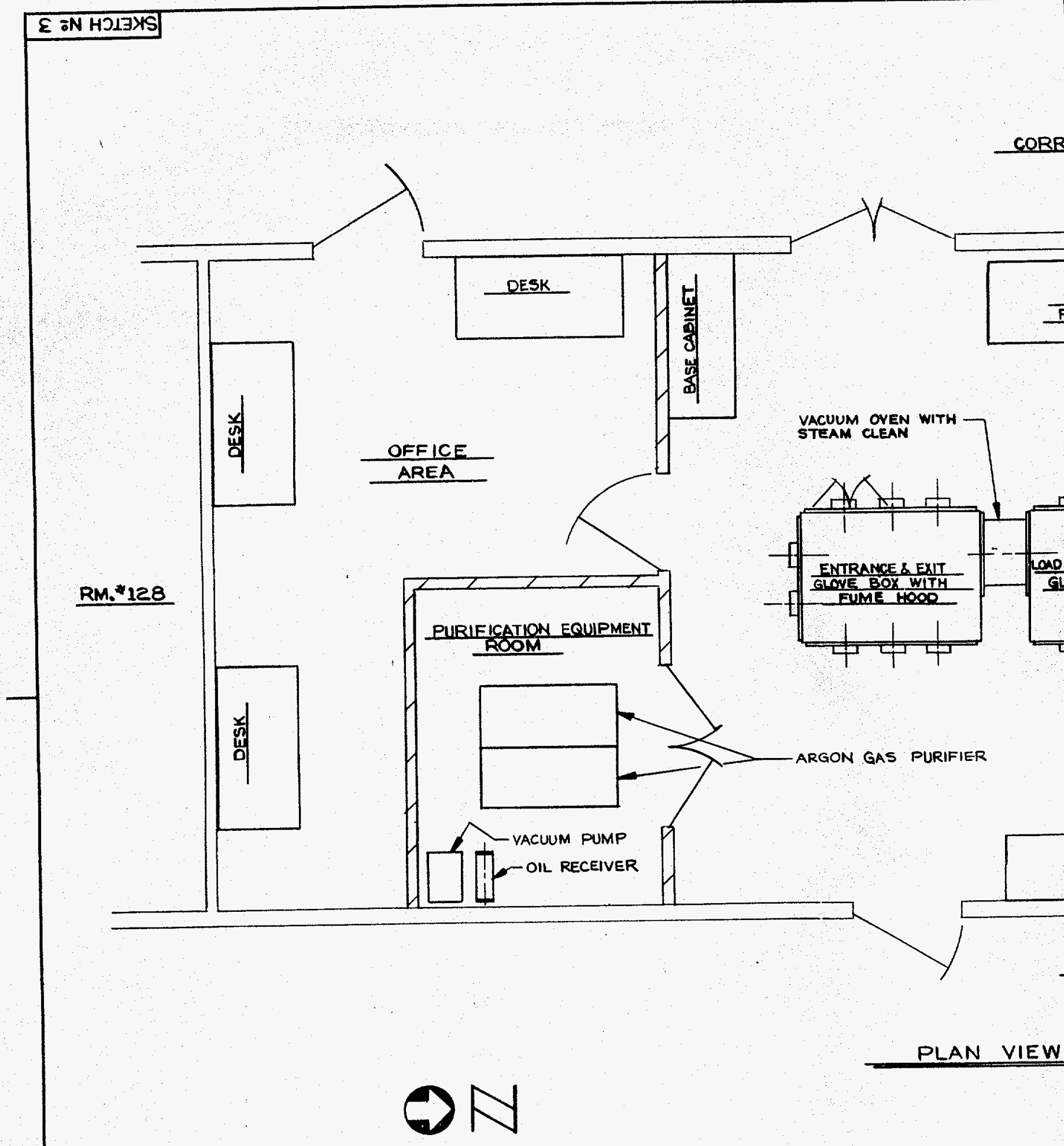


7-in. stainless steel air-operated gate valve. Ionization and Pirani gages will be included for monitoring the vacuum attained. All of the pumping system will be mounted below the deck of the vapor deposition glovebox. This area will be enclosed and exhausted to the fume hood exhaust system.

The vacuum chamber will consist of a 26 -in. diameter stainless steel base plate welded to the vapor deposition glovebox deck, and a 24-in. i.d. by 33-in. high stainless steel bell jar mounted inside the glovebox. The bell $\mathrm{j}$ ar will be raised and lowered with a motorized drive hoist, and will be equipped with water tubing for cooling or heating as required. All electrical feed throughs will penetrate the 26-in. diameter base plate with vacuumtype penetrations.

Two single-hearth electron beam guns with $x-y$ sweeps will be used for depositing the chromium and titanium films. A rotary drive system will support the target and rotate it at $5 \mathrm{rev} / \mathrm{min}$ about the electron beam source. A $6-\mathrm{kW}$ heater will provide the means of elevating the target temperature to $500^{\circ} \mathrm{C}$. A controller will be included to establish deposition rate and to control the $15-\mathrm{kW}$ power supply. All controls and instruments will be housed in the vapor deposition console.

The vacuum hydrogen furnace will be used for several operations. It will be used for hydrogen fire cleaning of targets prior to vapor deposition, as a vacuum furnace for recovering tritium from expended targets, and for tritiding the new or reused targets.

The vacuum hydrogen furnace consists of a vacuum pumping system, a vacuum-type furnace chamber, and a power supply for elevating the temperature of the furnace chamber to $700^{\circ} \mathrm{C}$.

The pumping system includes a 6-in. diffusion pump (capable of pumpdown to $1 \times 10^{-7}$ torr), a chevron-type baffle, a liquid nitrogen trap, and a 30- $\mathrm{ft}^{3} / \mathrm{min}$ mechanical pump. Foreline and roughing valves and the high-vacuum valve will be air-operated gate valves. Ionization and thermocouple gages will be included for monitoring the vacuum attained. All of the pumping system will be mounted below the deck of the hydride glovebox. This area will be enclosed and exhausted to the fume hood exhaust system. 
The furnace chamber will be mounted below and welded to the deck of the hydride glovebox. A hot zone 22 in. in diameter $\times 12$ in. high will be provided within the furnace chamber. This chamber will enable the processing of several targets at a time.

A saturable core power supply, strip chart recorder, programer, overtemperature controls and partial pressure hydrogen controls will be mounted in the vacuum furnace console.

A cleaning fixture using glass bead blast will be designed and installed in the cleaning glovebox. All remaining fixtures are used for inspecting, handling, and packaging/unpackaging of the targets.

\subsection{FACILITY COSTS}

Items in the following detailed facility cost estimate were derived from the process flow diagram presented in Section 3, p. 19. Equipment costs come from vendor price lists, quotes, and similar installations at Mound. Room modification costs are based on estimating guides and the experience of our professional estimator. Facility costs are based upon design, procurement, and installation occurring in FY-1978 and the first three quarters of FY-1979, and therefore will require escalation if the facility schedule (shown in Figure 4, p. 11) is delayed. Engineering, design, and inspection (E.D.\&I.) costs vary from project to project and are based on actual estimated needs of individual items, with the totals as shown being a composite of the individual E.D.\&I. costs. A contingency was established for each item dependent on the extent of detailed definition and confidence in our numbers. The total contingency shown is a composite of these individual contingencies.

Al1 of the capital items in this estimate are capability related. (See page 12 for Capital Cost Estimate.) 


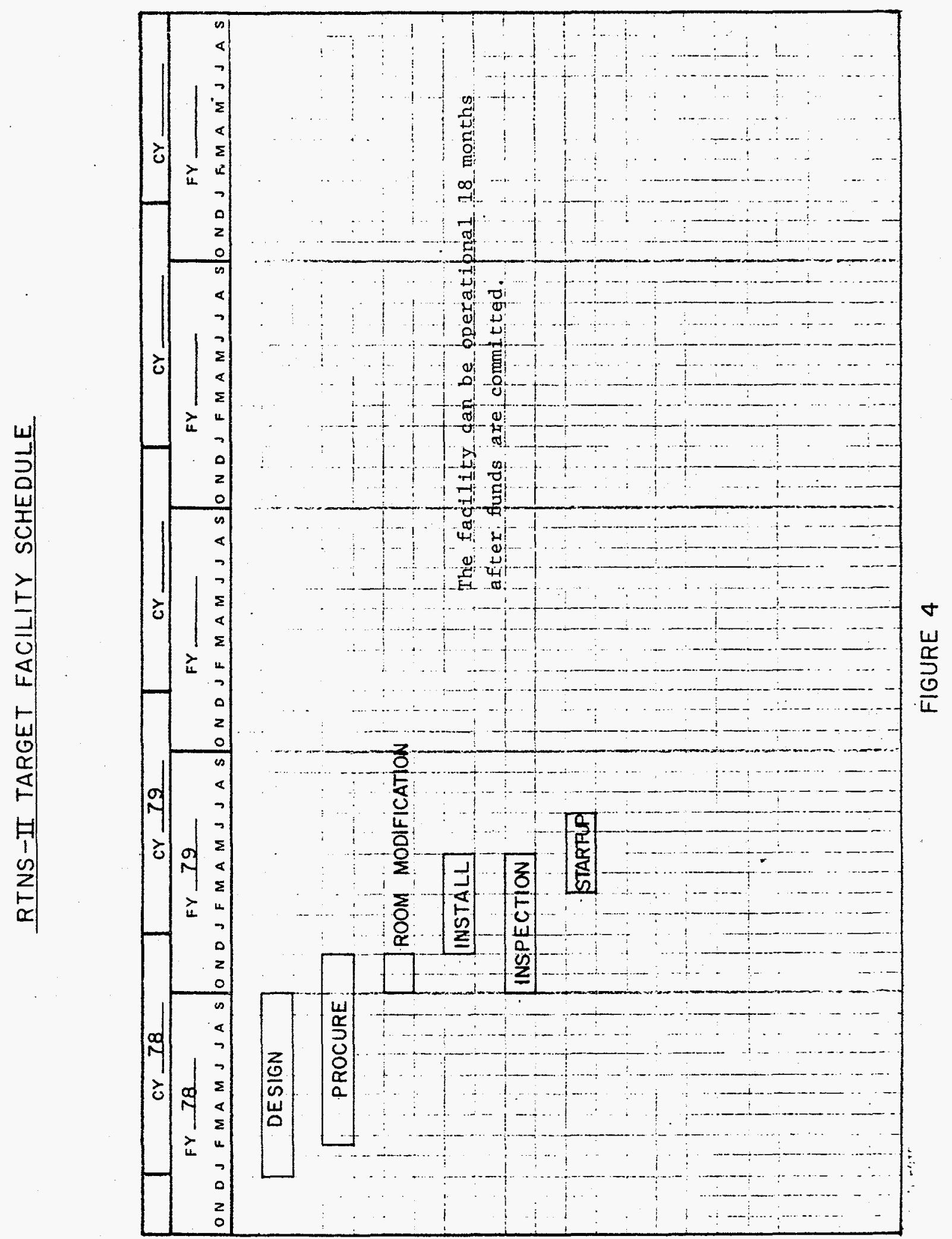


CAPITAL COSTS (dollars in thousands)

a. Engineering, Design, and Inspection

at $15 \%$ of Modification and Equipment Cost

b. Land and Land Rights

c. Modification and Equipment Cost

1. Improvements to Land

2. Room Modifications

Architectural Modifications

Ventilation Modifications

3. Other Structures

4. Special Facilities

Vacuum Deposition System

107

Vacuum/Hydrogen Furnace

Gloveboxes

Passboxes

Vacuum Oven with Steam Clean

Inert Gas System

Gas Analysis

Room Monitors

Fixtures

70

Process Piping

42

Process Electrical

Sub Total

5. Utilities

d. Standard Equipment

Fume Hood

Vacuum Pumps

Base Cabinets

Sub Total

e. Contingency at $22 \%$ of A11 other Costs

TOTAL PROJECT ESTIMATE (CAPITAL)

\section{FINANCIAL SCHEDULE}

Fiscal Year

1978

1979

Obligations
$\begin{gathered}\$ 500,000 \\ \$ 270,000\end{gathered}$

Costs

$\$ 400,000$

$\$ 370,000$ 


\subsection{OPTIONAL FACILITY}

A somewhat less expensive facility can be provided if the evaporator and some other supporting equipment are installed in an air environment. This type of installation would reduce capital costs for gloveboxes, fixturing and installation. The hydriding/ dehydriding operations and the loading/unloading functions would still be conducted in an inert glovebox environment. The estimated capital cost of this option is $\$ 600,000$.

Although less costly, this option imposes several serious limitations :

1) Recycle of used targets would not be possible; however, recovery of the tritium could still be accomplished by destroying the target.

2) The choice of occluder metals under consideration would be limited to $\mathrm{Cr} / \mathrm{Ti}$. Since target transfer from the evaporator to the hydriding operation would expose the occluder metal to air, significant contamination (oxides, nitrides, etc.) would occur with other occluder metals such as scandium.

3) Hydrogen fire cleaning could not be provided.

\subsection{PACKAGING COSTS}

The proposed packaging for the neutron source targets is envisioned to satisfy two main requirements:

1) On-site handling and temporary storage - This will be conveniently accomplished with DOT Type A packaging as shown in the conceptual sketch of Figure 5, p. 14.

2) Shipping - DOT Type B packaging will be required for shipment from Mound to LLL. This will be accomplished by placing several of the Type A packages into an existing, certified Type B overpack such as the protective Packaging, Inc.

"Ha1f-Supertiger" for transport by truck.

Features of the proposed packaging are:

a) Primary container - 0-ring-sealed flange cover with provision for gas purge and/or evacuation. 


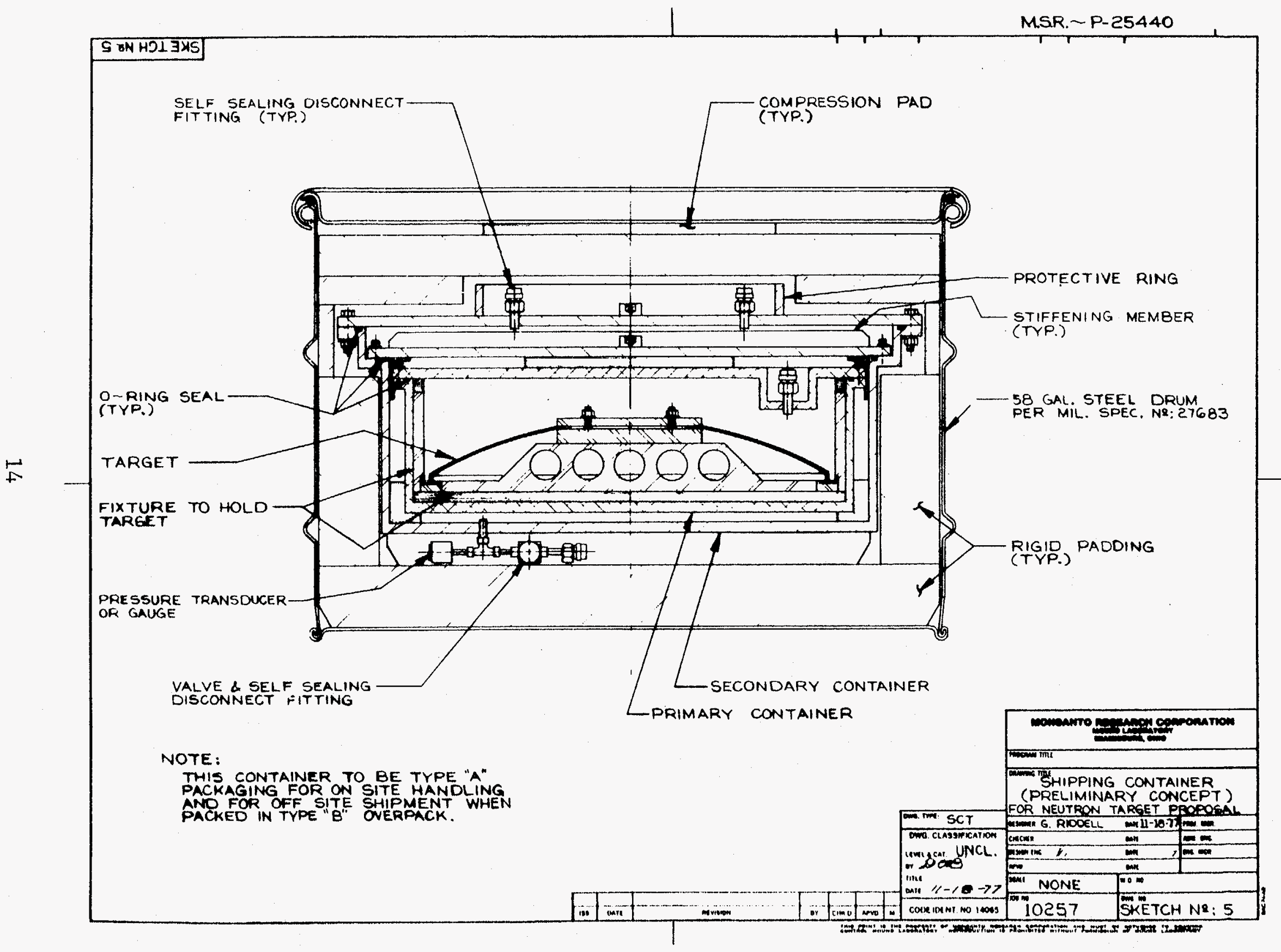

Figure 5 
b) Secondary container - 0-ring-sealed double flange cover for direct attachment to glovebox for minimum risk transfer of the primary container into and out of the glovebox. Provision is made for gas purge and/or evacuation as well as leak and contamination checks with covers in place.

c) Drum assembly - 58-gal steel drum (MS 27683) lined inside with protective padding.

\section{Container Development Cost}

Design

$\$ 8,000$

Prototype Fabrication, Testing, and Documentation

$\underline{14,000}$

TOTAL

$\$ 22,000$

Container Unit Cost

Fabrication of Type A

$\$ 8,000$ each 


\section{PROCESS OPERATIONS}

\subsection{INTRODUCTION}

Mound philosophy during preparation of this proposal has been to emphasize the need to produce RTNS-II tritided accelerator targets for LLL in as clean and inert an environment as is economically feasible, in order to ensure ultimate purity and stoichiometry of the final product. Therefore, the facility design and process operations presented stress that essentially all activities will be conducted in a high-purity argon atmosphere glovebox. The capability to process both new and expended targets as well as to recover and enrich tritium from expended targets was also emphasized.

The major operations involved in processing new and expended targets and the recovery and enrichment operations are summarized in the following paragraphs. (Further detail for these operations is given in the process flow diagram, Figure 6 , on p. 19. The location where each operation is performed is listed first.) The facility is sized to produce approximately 100 targets per year for a one-shift operation.

\subsection{NEW TARGET PROCESSING}

Receiving Fume Hood (Receiving, Inspection, Cleaning)

Targets are received, unpackaged and visually inspected. Accepted targets are vapor degreased, ultrasonically cleaned and transferred to the hydride glovebox by means of the $T$ passbox with sliding drawer.

Hydride Glovebox (Hydrogen Fire Cleaning)

Up to five targets are placed in the vacuum hydrogen furnace (capable of pumpdown to $1 \times 10^{-7}$ torr), heated, and hydrogen fire cleaned. The targets are cooled and inspected. Accepted targets are removed to the vapor deposition glovebox.

Vapor Deposition Glovebox (Vapor Deposition)

The target is placed in the vapor deposition unit bell jar (capable of pumpdown to $1 \times 10^{-7}$ torr) and heated, and the underlay and occluder films are deposited per specifications. The target is cooled and inspected. Accepted targets are moved to the hydride glovebox. 
Hydride Glovebox (Tritiding)

Accepted targets are placed in the vacuum hydrogen furnace, heated and exposed to a standard volume of high-purity tritium until the reaction goes to completion. The targets are cooled and the excess tritium is removed. The targets are then removed for inspection. Accepted targets are moved to the load/unload glovebox for packaging.

Load/Unload Glovebox (Packaging)

Each accepted target is placed in a primary container, and the primary container is helium leak checked. The accepted primary container is then pressurized with 400-500 torr of high-purity helium and moved to the vacuum oven with steam cleaning for decontamination.

Vacuum Oven with Steam Clean (Decontamination)

The primary container is decontaminated with steam and dried. It is then moved to the entrance/exit glovebox with fume hood.

Entrance/Exit Glovebox with Fume Hood (Shipping)

The primary container is inspected for contamination. The accepted primary container is placed in the secondary container. The secondary container is placed in a drum assembly as shown in Figure 5, p. 14. Several of these Type A assemblies are then loaded into a Type B overpack for shipment.

\subsection{EXPENDED TARGET PROCESSING}

Entrance/Exit Glovebox with Fume Hood (Receiving)

Targets are received packaged inside primary and secondary containers. The outer lid of the secondary container is removed after it has been placed inside the fume hood. The secondary container is mounted to the glovebox and the primary container is then removed from the secondary container. The primary container is moved to the load/unload glovebox. 
Load/Unload Glovebox (Unloading)

The target is removed from the primary container in a high-purity argon atmosphere. The target is then moved to the hydride glovebox.

Hydride Glovebox (De-tritiation)

Up to five targets are placed in the vacuum/hydrogen furnace and heated in a vacuum to remove hydrogen isotopes. The targets are cooled, removed, and inspected. If the underlay and occluder films are acceptable, the target is returned to the vacuum/hydrogen furnace for resubmission to a standard volume of high-purity tritium. The accepted target is then moved to the load/unload glovebox. The subsequent loading into a primary container, decontamination, and final packaging for shipment are as previously described for new loaded targets. If the underlay and occluder film are unacceptable, the rejected target is moved to the cleaning glovebox.

\section{Cleaning Glovebox (Cleaning)}

The target is cleaned in a glass bead blast fixture, degreased, and inspected. The accepted target is then moved to the hydride glovebox. The targets then undergo hydrogen fire cleaning, vapor deposition, hydriding, container loading, decontamination, and final packaging as described for new target processing.

\subsection{TRITIUM RECOVERY AND ENRICHMENT}

Hydride Glovebox (Tritium Recovery and Enrichment)

When the expended targets are heated in a vacuum to remove hydrogen isotopes, the recovered hydrogen is piped to a tritium recovery area where it is purified and then transferred to the thermal diffusion area for tritium enrichment to greater than $99 \%$. This tritium is returned to a calibrated tritium tank from which a standard volume is added to a target in the vacuum/hydrogen furnace for hydriding as previously described. 


\subsection{OPERATING COSTS}

Direct operating costs for processing new and expended targets and the recovery and enrichment operations were obtained by adding estimated unit costs for labor, material and direct support. Costs are for FY-1979 and therefore require escalation for year of operation. Unit costs were based on an assumed acceptance rate of $95 \%$ and a production rate of 100 targets per year for a one-shift operation. With two-shift operation an additional correspondent number of targets $c$ an be produced. Direct labor costs were arrived at by:

a) Creation of a process flow diagram.

b) Outlining detailed operating procedures.

c) Assignment of standard hours to each operation.

d) Conversion of standard hours to procured hours using industrial engineering factors for vacations, holidays, clerical work, meetings and various production delays.

e) Conversion of procured hours to procured dollars by multiplying by the average hourly rate.

\section{COST PER TARGET (Dollars)}

$$
\text { (FY-1979) }
$$

\section{Operation}

a) New Target Processing*

$\$ 993$

b) Expended Target Processing*

975

C) Tritium Recovery and Enrichment

* Cost of tritium is not included. 


\section{HAZARDS EVALUATION}

\subsection{SUMMARY}

The proposed project to manufacture tritiated targets at Mound Facility will not present any undue risk of accident or exposure to employes or the public. A quantity of $5 \times 10^{4} \mathrm{Ci}$ would be the maximum quantity available for release from the process facilities and this material is contained in a double-walled stainless vessel. Accidental release of this total quantity from the storage vessel would result in an estimated potential exposure of 0.05 rem to employes, which is below Federal guidelines and would have negligible effect upon the environment. Normal effluents would be expected to release $75 \mathrm{Ci}$ per year which would result in doses to the public of less than $10 \%$ of that from background tritium.

\subsection{INTRODUCTION}

\section{Purpose}

The purpose of this hazards analysis is to identify and document the risks associated with the proposed project to manufacture tritiated targets for LLL. Accordingly, this analysis considers the experience of Mound Facility in handling and processing large quantities of tritium in production programs, the tritium containment technology developed and utilized at Mound, and the possible consequences of releases of tritium to the environment by either accident or normal effluents.

\subsection{PROCESS SAFETY AND ENVIRONMENTAL PROTECTION FEATURES}

Mound Facility has over $20 \mathrm{yr}$ of experience in handling and processing large quantities of tritium in production as well as research and development programs. Development and utilization of tritium containment technology at Mound during these $20 \mathrm{yr}$ has resulted in improved employe exposure controls and markedly reduced environmental releases. Some of the more innovative effluent control features which enable Mound to maintain tritium effluent levels at the lowest practicable levels at the actual point of emission (stack) are discussed below. 


\section{Containment}

The primary safety feature is the design and operating philosophy of total containment of all radioactive materials. Multiple containment of tritium gas and tritiated materials assures protection of employes and the environment. Primary containment for tritium gas will be stainless steel pipelines and vessels and secondary containment will be provided by recirculating inert-atmosphere gloveboxes.

Tritium in the glovebox atmosphere is removed by oxidation to water and removal by drying the inert gases. As a result of the lowered tritium content of the glovebox atmosphere, greatly reduced effluent releases occur from diffusion during normal operations, and personnel exposures are correspondingly reduced.

All pressure vents on the recirculating systems will be vented to the ERS to provide an additional level of protection to the environment.

\section{Vacuum Oven with Steam Clean}

Anything removed from tritium glovebox lines must first be decontaminated to minimize release of tritium to the environment. Provisions for effective decontamination will be made by installing a vacuum oven with provisions for steam cleaning in the glovebox line. This unit will permit sealed containers and equipment to be decontaminated using steam. The liberated hydrogen and tritiated water will be pumped to the ERS. Experience with this technique at Mound has been very favorable and is another example of the steps now being taken to reduce tritium effluents.

\section{Effluent Removal System}

The ERS currently services tritium operations in the SW Building. This system, which has been in operation for over $12 \mathrm{yr}$, is used to remove tritium as water from the effluents of various support equipment such as vacuum pumps and inert-gas purifiers before the gases are exhausted to the atmosphere. A flow diagram of the ERS is provided in Figure 7, p. 23. 


\section{EFFLUENT REMOVAL SYSTEM}

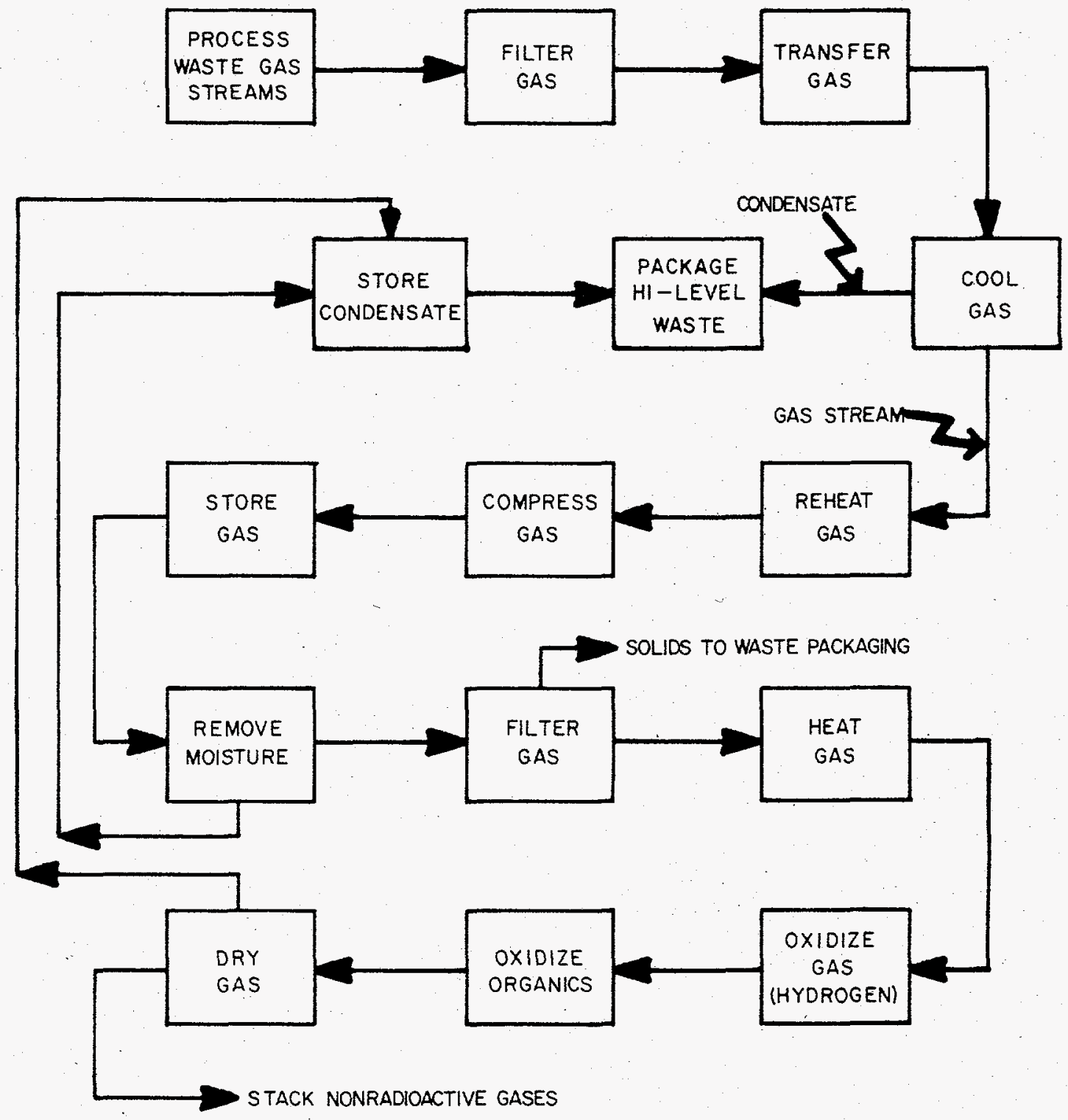


The effectiveness of these tritium containment design features and effluent control systems coupled with strong, active management emphasis on maintaining radioactive effluents and personnel exposures as low as practicable can be seen from the following charts (Figures 8, 9, and 10, pp. 25, 26, and 27). One important feature of the Mound effort to reduce releases to the environment to as-low-as-practicable levels is the establishment of goals on an annual basis. This has helped Mound to achieve a reduction in the quantity of tritium released into the air by a factor of 50 since 1969. An even greater reduction, by a factor of 200, has been achieved in the quantity of tritium released in water since 1969.

Aggressive monitoring, training and review programs, as a consequence of the dedicated management emphasis on development of tritium containment technology, have also reduced the average absorbed dose from tritium by Mound personnel from $0.256 \mathrm{rem} /$ person in 1971 to an average of $0.0175 \mathrm{rem} /$ person in 1976. This represents a reduction in average absorbed dose by a factor of approximately 14 . This is less than $0.4 \%$ of the standard as spelled out in DoE Manual Chapter 0524.

\subsection{ACCIDENT ANALYSIS}

A review of the proposed operations and facilities was conducted to identify those process steps having the greatest potential for accidents which could result in exposures to employes or in environmental releases of tritium. The basis for determining this capability was the presence of relatively large quantities of tritium in the process step and/or other significant hazards which could conceivably result in some sort of accident such as explosion, fire, or equipment malfunction. The in-process storage of tritium gas was identified as having the most potential for accidental release of tritium. The possible consequences of such an accident and the design features which prevent or mitigate the consequences of this accident are discussed below.

Storage of Tritium Gas

Since the process will obtain tritium gas from the existing SW Building recovery facilities, requirements for storage of tritium gas will be limited to approximately $5 \mathrm{~g}$. This storage will be achieved in a double-walled stainless steel vessel, which is enclosed in a glovebox. Tritium monitors within the glovebox will automatically direct the exhaust to the ERS should a leak occur. 


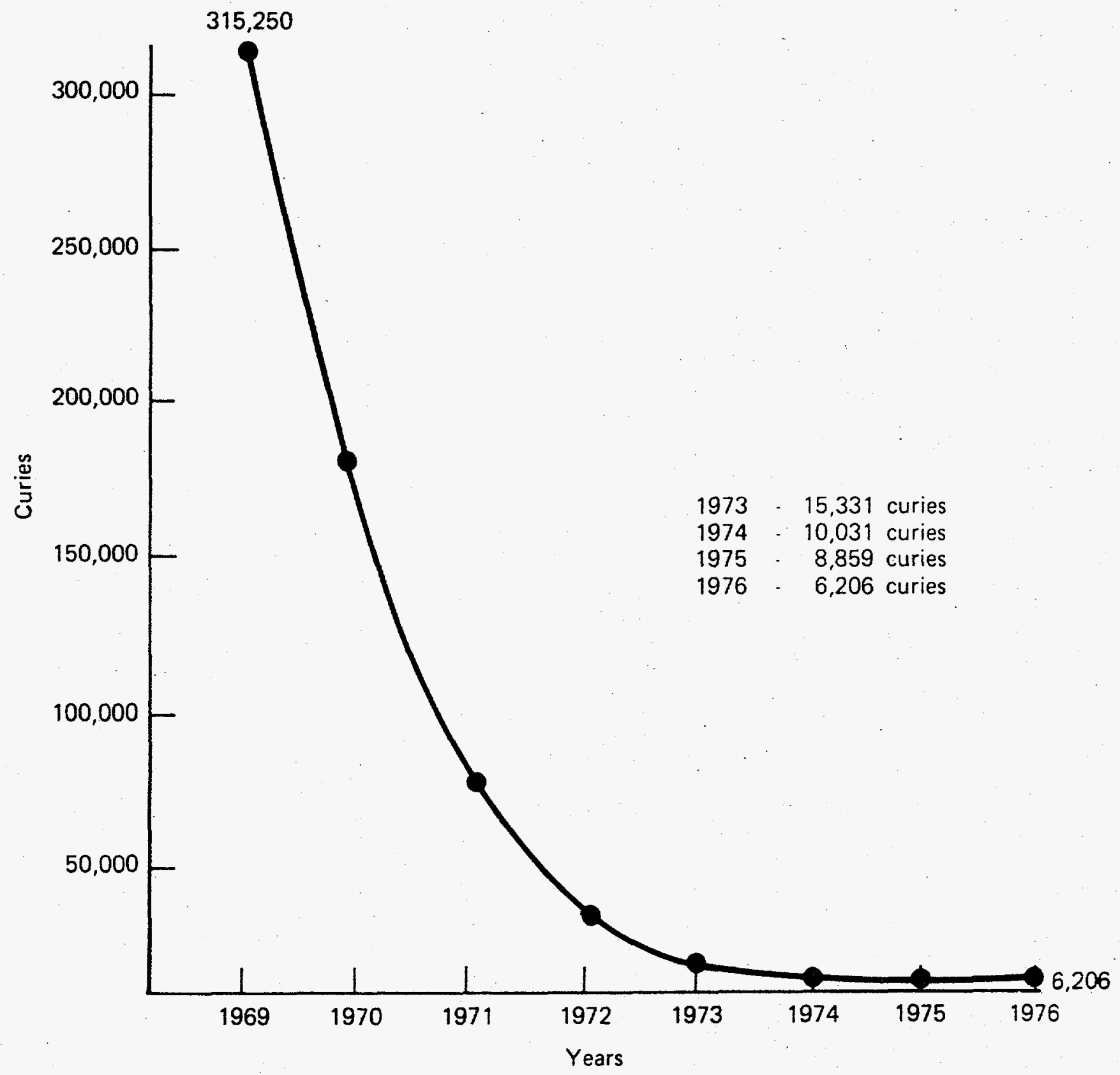

Tritium released in air has been reduced by a factor of $\sim 50$ since 1969 .

FIGURE 8 - Tritium Released in Air. 


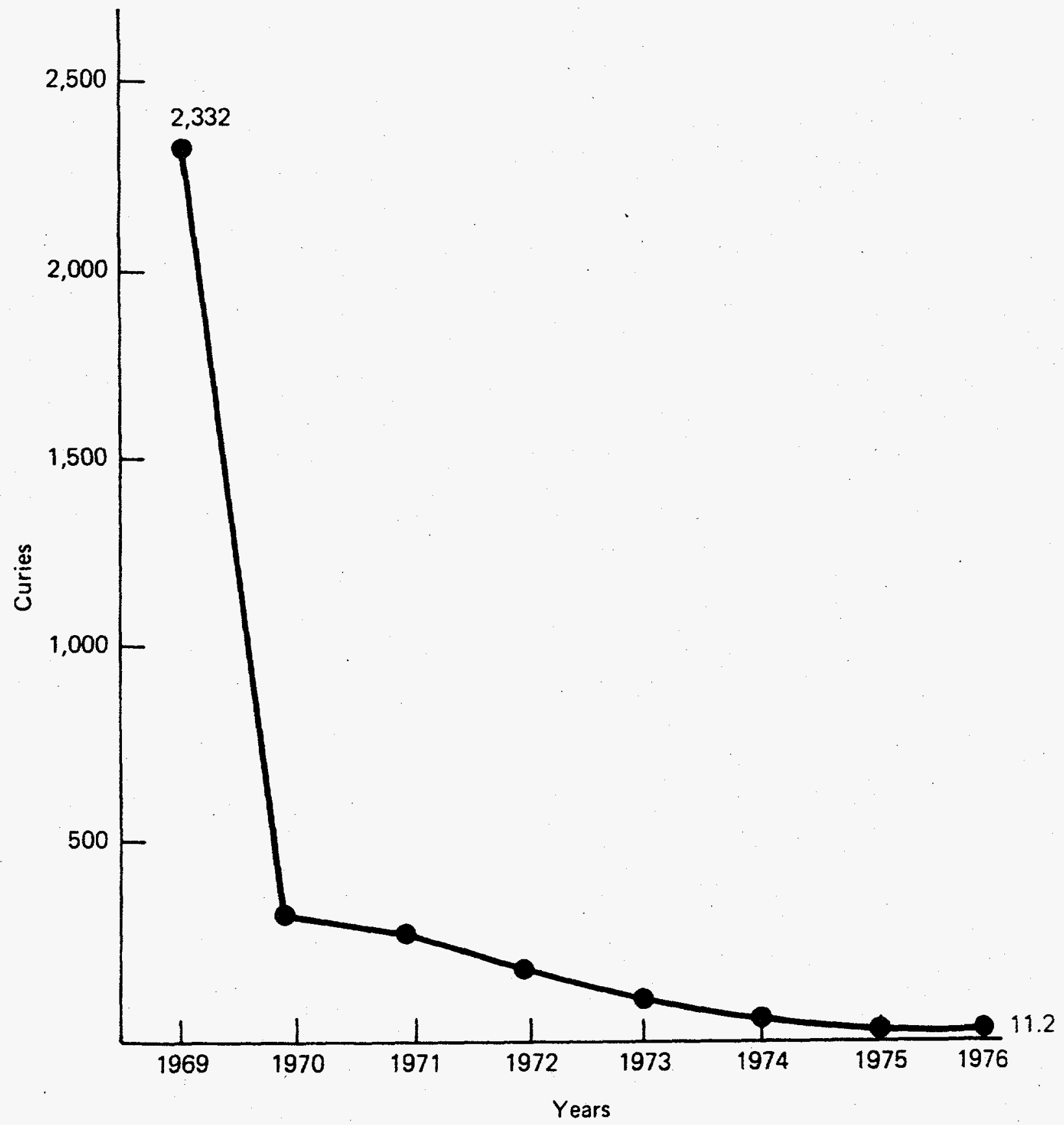

Tritium released in waterborne effluent has been reduced by a factor of $\sim 200$ since 1969 .

FIGURE 9 - Tritium Released in Water. 


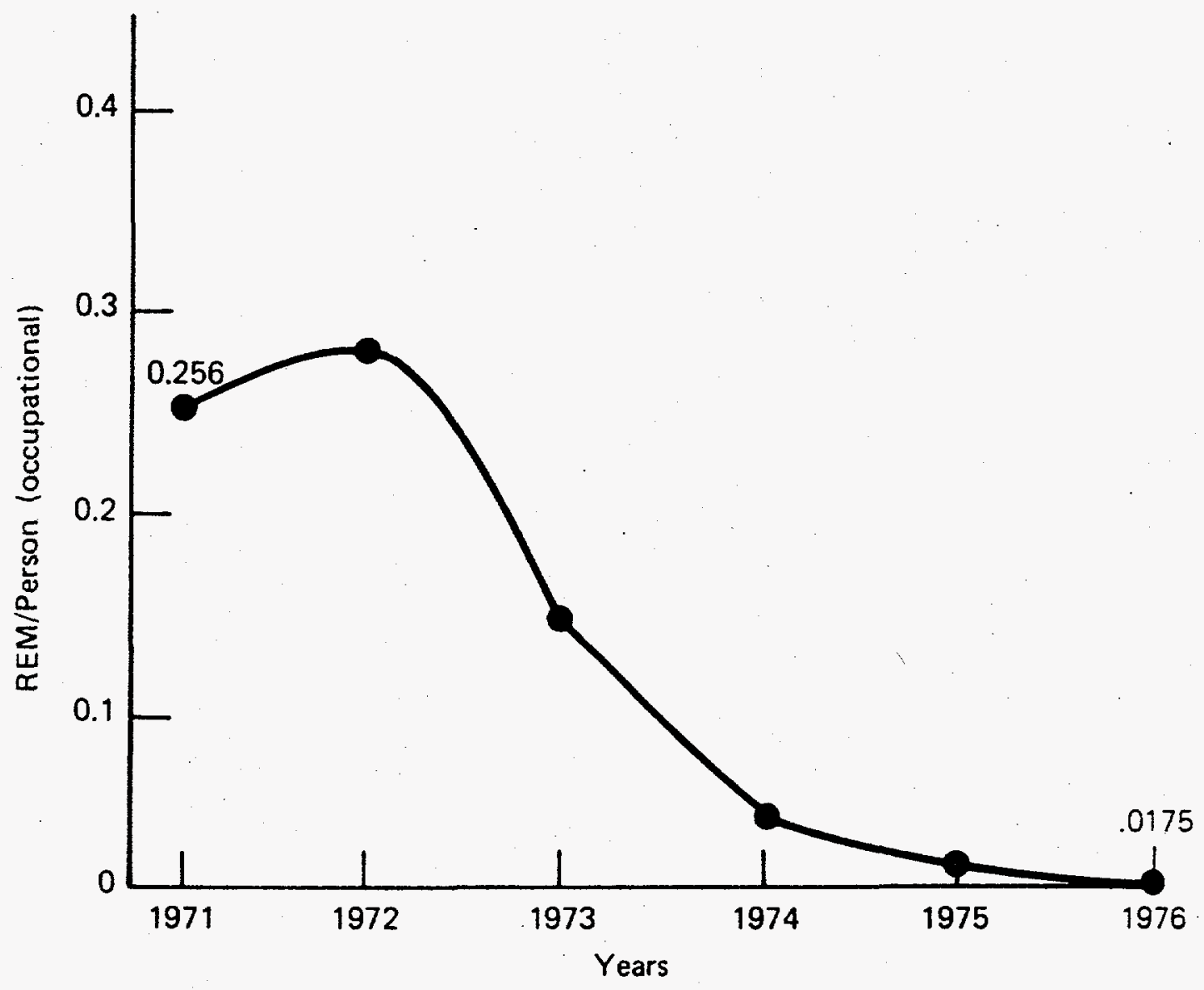

Average tritium exposure has been reduced by a factor of $\sim 14$ since 1970 .

FIGURE 10 - Tritium Exposures. 
Conceivably a valve or pipeline failure could result in release into the glovebox of the total quantity of stored tritium gas. Based on past experiences at Mound with similar systems, a release of $5 \mathrm{~g}$ or $5 \times 10^{4} \mathrm{Ci}$ of tritium gas into the glovebox could be expected to result in a total release to the environment on the order of $10 \mathrm{Ci}$. This release would result in no significant impact to the environment or the public. Permeation and leakage of tritium from the glovebox would result in some potential exposure to any employes remaining in the room. Again, experience with similar releases indicates that room concentrations could be expected to reach $200 \mu \mathrm{Ci} / \mathrm{m}^{3}$ for periods of up to several hours. Exposures to personnel would be dependent on several factors, including the percentage of tritium as water vapor versus molecular tritium, the length of time personnel were exposed to the tritium, and the degree of protection provided by the type of clothing worn. Assuming that fully $50 \%$ of the tritium in the room would be in the form of oxide or water vapor and assuming no credit for protection offered by clothing, exposure times of $1 \mathrm{hr}$ would lead to calculated doses to personnel of approximately 0.05 rem. This exposure is within Federal guidelines set forth in DoE Manual Chapter 0524.

$\underline{\text { Person-Rem Estimates }}$

Some releases of tritium would occur from normal operations because of diffusion of small amounts of tritium through glovebox gloves and because of some extremely small release from the ERS. Based on quantities of tritium handled in similar operations and measured normal effluents, it is conservatively estimated that a maximum of $75 \mathrm{Ci}$ would be released during a period of $1 \mathrm{yr}$. This compares to approximately $6200 \mathrm{Ci}$ which was released from all tritium operations at Mound during CY-1976. Since the Facility maintains an extensive environmental monitoring program, data are available on the distribution of tritium in the environment from long-term Facility effluents. Estimates of annual doses to the public have been prepared based on these actual data. Realistic estimates of doses from projected low-level, long-term releases can thus be obtained by comparing the anticipated quantity to be released to the quantity released in the previous year and assuming that the environmental distribution follows the same general pattern as the previous year. During CY-1976, approximately $6200 \mathrm{Ci}$ was 
released to the atmosphere and the dose to the public from this quantity was approximately 8.5 person-rem, which is approximately the level received from background tritium in the environment. Estimated annual releases from the proposed project are $75 \mathrm{Ci}$ per year which would result in a dose to the public of approximately 0.1 person-rem. This is about $10 \%$ of the dose level received by the public from background tritium. 


\section{DISTRIBUTION}

EXTERNAL

D. H. Ahman, GEND

V. V. Berniklau, ALO

W. C. Brown, GEND

J.A.Chacon, DoE/DAO

J. C. Davis, LLL (3)

D. K. Nowlin, ALO

D. Ofte, DoE/PAO

V. C. Vespe, ALO

\section{INTERNAL}

H. F. Anderson

R. P. Bowser

J. D. Braun

W. T. Cave

W. A. Clift

D. L. Coffey

C. W. Huntington

L. V. Jones

B. R. Kokenge

J. R. McClain

E. A. Mershad

L. W. Metcalf

G. V. Nesslage

A. R. Stambaugh

R. A. Watkins

R. E. Wieneke

H. L. hilliams 